\title{
GAMBARAN BODY IMAGE PASIEN PASCA AMPUTASI TRANSTIBIAL SETELAH MENGGUNAKAN TRANSTIBIAL PROSTHESIS
}

\author{
Maretania Devi Maya Santi, Nur Rachmad \\ Politeknik Kesehatan Kementarian Kesehatan Surakarta, Jurusan Ortotik Prostetik \\ Diterima : 6 Oktober 2018, Disetujui : 10 Oktober 2018 \\ e-mail : maretaniadevi9@gmail.com
}

\begin{abstract}
Background, Individual assessment of the body and its appearance is called the term body imagel self image (body image). In the act of amputation is closely related to the body image that ultimately affects the self-image of a person's appearance both psychologically and psychologically. Transfoliative amputation clients report social discomfort associated with changes in body image, negative body esteem, lack of social support and increased depression and post-traumatic stress disorder. Transtibial Prosthesis is an instrument intervention in the form of a prosthesis by being paired outside the body which aims to restore the lower limb shape and can replace the function anatomically and functionally is expected also able to increase the confidence physically and psychically to the body image (form body) of patients with transtibial amputation. Method: type is qualitative with research method that is used that is interview and observation. Result: That the increase of body image transtibial amputations after using the transtibial prosthesis. Conclusion: Based on the results of observations, interviews and analysis carried out on the use of Transtibial Prosthesis, patients now feel progress in their activities thanks to using prosthesis especially when the activity must be in public
\end{abstract}

Keywords : Body Image;Amputation;Transtibial Prosthesi

\section{PENDAHULUAN}

Amputasi dapat diartikan sebagai tindakan memisahkan bagian tubuh sebagian atau seluruh bagian ekstremitas. Tindakan ini merupakan tindakan yang dilakukan dalam kondisi pilihan terakhir manakala masalah organ yang terjadi pada ekstremitas sudah tidak mungkin dapat diperbaiki dengan menggunakan teknik lain, atau manakala kondisi organ dapat membahayakan keselamatan tubuh klien secara utuh atau merusak organ tubuh yang lain seperti dapat menimbulkan komplikasi infeksi (healthy enthusiast). Menurut Qkey sekitar 75\% amputasi terjadi pada pria. Baik amputasi yang terjadi karena pekerjaan, penyakit dan penyebab lain, insidennya lebih tinggi pada pria. $85 \%$ amputasi terjadi pada ekstremitas bawah dan indikasi pada amputasi ada 3D yaitu: (1) Dead (dying), (2) Dangerous, (3) damn nulsance.

Berdasarkan penelitian, pada saat ini amputasi pada alat gerak bawah mencapai $85-90 \%$ dari seluruh amputasi dan amputasi bawah lutut (transtibial amputation) merupakan jenis operasi amputasi yang paling sering dilakukan (Vitriana, 2002). Menurut Vitriana angka insidensi dan prevalensi amputasi yang pasti tidak diketahui, tetapi di Amerika Serikat saat ini terjadi 43.000 amputasi per tahun dari jumlah penduduk 280.562.489 jiwa atau sekitar $0,02 \%$ sedangkan 
menurut Raichle et al. (2009) disebutkan bahwa terjadi kasus amputasi sekitar 158.000 per tahun dari jumlah penduduk 307.212.123 atau sekitar 0,05\% dan terjadi kenaikan baik secara jumlah maupun secara persentase dari jumlah penduduk.

Penyebab amputasi dan kondisi medis yang berhubungan dengannya sering menjadi pertimbangan yang penting untuk mengembangkan program manajemen pasien dengan amputasi. Penyebab amputasi sendiri secara umum dapat dibedakan menjadi : (1) efek lahir congenital 5\% dengan mayoritas tampak pada usia dari lahir hingga 16 tahun, (2) penyakit oklusi arterial $60 \%$ yang sering dihubungkan dengan diabetes mellitus dengan insidensi pada usia sekitar 60-70 tahun $90 \%$ kasus melibatkan alat gerak bawah, (3) trauma, maupun (4) kecelakaan lalu lintas.

Klien pasca amputasi tungkai bawah melaporkan ketidak - nyamanan sosial yang terkait dengan perubahan citra tubuh, body esteem negatif, kurangnya dukungan sosial dan meningkatnya depresi dan gangguan stres pasca-trauma. Orang-orang dengan amputasi biasanya melaporkan kemarahan, kesedihan, tidak berdaya, frustasi, kecemasan dan rasa bersalah, serta kekhawatiran tentang keluarga, pekerjaan, hubungan sosial dan seksual. (Rybarczyk 2005, et al, McCabe 2005, et al.).

Dalam tindakan amputasi sangat berkaitan erat pada citra tubuh yang pada akhirnya berpengaruh terhadap citra diri penampilan seseorang baik secara psikis maupun psikologis. Penilaian individu terhadap tubuh dan penampilannya disebut dengan istilah citra tubuh/ citra diri (body image).
Menurut Cash (1994) citra tubuh adalah penilaian dari pengalaman perasaan seseorang mengenai karakteristik dirinya. Honigam dan Castle mengatakan citra tubuh adalah gambaran mental, persepsi, dan penilaian seseorang terhadap pikiran dan perasaannya yang berkaitan dengan bentuk dan ukuran tubuhnya, serta penilaian orang lain terhadap dirinya. Hoyt (dalam Naimah, 2008) menyebutkan citra tubuh adalah sikap individu terhadap ukuran, bentuk, dan estetika tubuhnya berdasarkan evaluasi individual dan pengalaman afektif terkait atribut fisiknya. Secara luas, citra tubuh dapat diartikan sebagai evaluasi subjektif dari penampilan seseorang.

Transtibial Prosthesis adalah suatu intervensi alat yang berupa alat gerak ganti (prosthesis) dengan cara dipasangkan diluar tubuh yang bertujuan untuk mengembalikan bentuk tungkai bawah dan dapat mengganti fungsi secara anatomis maupun fungsional yang diharapkan juga mampu menambah kepercayaan diri secara fisik maupun psikis terhadap citra tubuh (bentuk tubuh) pasien yang mengalami amputasi transtibial. Transtibial prosthesis memiliki berbagai macam desain yang setiap desainnya memiliki maksud dan tujuan sesuai kebutuhan pengguna. Desain yang ditentukan akan berpengaruh terhadap komponen dari transtibial prosthesis. Transtibial prosthesis terbagi menjadi 3 komponen yakni socket, shank, dan foot (Handicap International, 2006). Komponen tersebut juga memiliki jenis/ tipe berbeda- beda yang disesuaikan dengan fungsi dan kemampuan dari pengguna melalui prescription yang diberikan oleh ortotis prostetis dengan berkonsultasi terlebih dahulu bersama pasien. 
Mengutip pada Permenkes RI no.22 tahun 2013, Ortotik Prostetik adalah sebuah pelayanan kesehatan yang diberikan oleh Ortotis Prostetis dalam hal alat bantu kesehatan berupa orthosis maupun prosthesis untuk kesehatan fisik psikis berdasarkan ilmu pengetahuan dan teknologi untuk meningkatkan derajat kesehatan individu, kelompok dan masyarakat yang diakibatkan oleh adanya gangguan fungsi dan gerak anggota tubuh dan trunk (batang tubuh) serta hilangnya bagian anggota gerak tubuh yang dapat mengakibatkan kelainan/ gangguan anatomis, fisiologis, psikologis dan sosiologis.

Mengacu pada uraian diatas peneliti melakukan proses observasi sebagai studi pendahuluan untuk mengumpulkan informasi sebagai landasan dalam penelitian. Menurut observasi dan kejadian diatas, peneliti tertarik untuk melakukan penelitian mengenai gambaran citra tubuh pasien amputasi transtibial dengan menggunakan transtibial prosthesis. Untuk itu peneliti ingin melakukan observasi dan wawancara kepada responden untuk mengetahui seberapa besar gambaran citra tubuh pasien ketika mengunakan prosthesis dalam kehidupan sehari-hari. Penelitian ini terfokus pada bagaimana konsep citra tubuh pasien amputasi transtibial menggunakan alat ganti gerak yakni transtibial prosthesis dengan harapan pasien bisa menggunakan prosthesis sebagai alat yang bisa membantu mereka menjadi lebih nyaman, optimis dan lebih mandiri.

\section{METODE PENELITIAN}

Penelitian ini menggunakan penelitian kualitatif. Penelitian kualitatif menghasilkan dan mengolah data yang bersifat deskriptif. Dalam penelitian ini, penulis ingin memberikan deskripsi mengenai perubahan beberapa aspek pada pasien penyandang amputasi transtibial yang menggunakan transtibial prosthesis, dan tidak ada hipotesis yang diuji meskipun menggunakan teori yang ada.

Metode penelitian yang digunakan dalam penelitian ini adalah penelitian ini dilakukan dengan studi kasus yang bersifat intrinsik, yaitu kasus yang diambil merupakan kasus yang menarik untuk diteliti. Menurut Moleong (1998) studi kasus merupakan metode untuk menghimpun dan menganalisis data berkenaan dengan studi kasus. Sesuatu dijadikan studi kasus biasanya karena ada masalah, kesulitan, hambatan, penyimpangan, tetapi bisa juga sesuatu dijadikan kasus meskipun tidak ada masalah, melainkan karena keunggulan atau keberhasilannya.

Tujuan dari studi kasus adalah untuk memberikan gambaran secara mendetail tentang latar belakang, sifatsifat serta karakter yang khas dari kasus, ataupun status dari individu, yang kemudian dari sifat-sifat khas tersebut akan dijadikan suatu hal yang bersifat umum.

Sedangkan menurut Moleong (2000) pendekatan kualitatif adalah pendekatan yang bermaksud untuk memahami fenomena tentang apa yang dialami oleh subjek penelitian misalnya perilaku persepsi, motivasi, tindakan dan lain- lain. Secara holistik, dan dengan cara deskripsi dalam bentuk kata-kata dan bahasa, pada suatu konteks khusus yang alamiah dan dengan memanfaatkan berbagai metode alamiah.

Pendekatan penelitian adalah murni kualitatif dengan menggunakan metodemetode kontak langsung, yakni 
wawancara. Peneliti akan melakukan penelitian kualitatif dengan metode pengumpulan data secara wawancara terfokus (Poerwandari. 2001). Efektivitas penggunaan transtibial prosthesis terhadap body image pasien amputasi transtibial ini akan diteliti dari data konkrit. Dimana subjek penelitian ini pasien amputasi transtibial dengan cara wawancara terfokus langsung pada pasien yang bersangkutan.

\section{Metode Pengumpulan Data}

Tehnik pengumpulan data yang akan digunakan dalam penelitian ini adalah wawancara dan observasi.

\section{Wawancara}

Menurut Poerwandari (2001) Wawancara adalah proses memperoleh keterangan untuk tujuan penelitian dengan cara tanya jawab sambil bertatap muka antara pewawancara dengan responden dengan mengunakan alat untuk mencapai tujuan tertentu yang mana adalah percakapan dan tanya jawab yang diarahkan untuk mencapai tujuan tertentu. (Poerwandari, 2001) membedakan wawancara pada tiga pendekatan dasar, yaitu :

\section{a. Wawancara mendalam (indepth interviewing)}

Proses wawancara didasar sepenuhnya pada berkembangnya pertanyaan- pertanyaan secara spontan dalam interaksi alamiah. Tipe wawancara demikian umumya dilakukan peneliti yang melakukan observasi partisipatif.

b. Wawancara dengan pedoman umum

Dalam proses wawancara ini, peneliti dilengkapi pedoman wawancara yang sangat umum, yang mencantumkan isuisu yang harus diliput tanpa menentukan urutan pertanyaan. Pedoman wawancara ini digunakan untuk mengingat peneliti mengenai aspek-aspek yang harus dibahas sekaligus menjadi daftar pengecek (checklist).

c. Wawancara dengan pedoman terstandar yang terbuka

Pedoman wawancara ditulis secara rinci, lengkap dengan set pertanyaan dan penjabarannya dalam kalimat. Peneliti diharapkan dapat melaksanakan wawancara sesuai konsekuensi yang tercantum.

\section{Observasi}

Menurut Patton (dalam Poerwandari, 2001) salah satu hal yang penting tetapi sering dilupakan dalam observasi adalah mengamati hal yang tidak terjadi. Pada penelitian ini, peneliti melakukan observasi di tempat tinggal pasien. Peneliti melakukan observasi pada pasien amputasi saat menjalankan aktivitas sehari-hari menggunakan transtibial prosthesis.

Observasi dilakukan untuk mengamati segala aktivitas pasien amputasi transtibial di lingkungan tempat tinggalnya. Menurut Carwright (1984), tujuan dilakukannnya observasi adalah untuk mengamati dan merekam informasi tingkah laku yang dilakukan secara sistematis

Peneliti akan melakukan wawancara dengan pedoman wawancara yang terbuka. Pedoman wawancara ditulis secara umum, dengan pertanyaan dan penjabarannya yang bersifat fleksibel dalam kalimat. Peneliti akan melakukan wawancara kepada keluarga yang secara terus menerus berhadapan langsung dengan pasien, sehingga diharapkan dapat mengetahui secara rinci bagaimana gambaran pasien amputasi transtibial ketika menggunakan transtibial prosthesis. Pertanyaan wawancara terdiri atas pertanyaan tentang kondisi citra tubuh 
subjek sebelum menggunakan prosthesis dan pertanyaan tentang kondisi subjek setelah menggunakan prosthesis.

Hasil observasi menjadi data yang penting karena :

a. Peneliti akan mendapatkan pemahaman yang lebih baik tentang konteks yang akan diteliti.

b. Observasi memungkinkan peneliti untuk bersikap terbuka, berorientasi pada penemuan dari pada pembuktian dan mempertahankan pilihan untuk mendekati masalah secara induktif. Dengan berada dalam situasi lapangan yang nyata, kecenderungan untuk dipengaruhi berbagai konseptualisasi tentang topik yang diamati akan berkurang.

c. Mengingat individu yang telah sepenuhnya terlibat dalam konteks hidupnya sering mengalami kesulitan merefleksikan pemikiran mereka tentang pengalamannya, observasi memungkinkan peneliti melihat halhal yang oleh subjek penelitian sendiri kurang disadari.

d. Observasi memungkinkan peneliti memperoleh data tentang hal-hal yang karena berbagai sebab tidak diungkapkan oleh subjek penelitian secara terbuka dalam wawancara.

e. Jawaban terhadap pertanyaan akan diwarnai oleh perspektif selektif individu yang diwawancara. Berbeda dengan wawancara, observasi memungkinkan peneliti bergerak lebih jauh dari persepsi selektif yang ditampilkan subjek penelitian atai pihak-pihak lain.

f. Observasi memungkinkan peneliti merefleksikan dan bersikap introspektif terhadap penelitian yang dilakukannya. Impresi dan perasaan pengamat akan menjadi bagian dari data yang pada gilirannya dapat dimanfaatkannya untuk memahami fenomena yang diteliti.

Menurut Moleong (2000), berdasarkan keterlibatan pengamat dalam kegiatan orang-orang yang diamati, observasi dapat dibedakan menjadi:

a. Observasi partisipan Pengamatan berperan serta melakukan dua peran sekaligus yaitu sebagai dan sekaligus menjadi anggota resmi dari kelompok

Yang diamatinya

b. Observasi non partisipan Pengamat tidak berperan serta hanya melakukan fungsi yaitu mengadakan pengamatan. Dalam pengamatan ini peneliti menggunakan bentuk observasi non partisipan dimana peneliti tidak mengamati tingkah laku subjek dan tidak ikut aktif dalam kegiatan subjek, karena peneliti hanya sebagai pengamat.

\section{Alat Bantu Pengumpul Data}

Menurut Poerwandari (2001) peneliti sangat berperan dalam seluruh proses penelitian mulai dari memilih topik, mendekati topik, mengumpulkan data, analisis, interpretasi dan menyimpulkan hasil penelitian. Dalam penelitian ini, peneliti menggunakan tiga instrumen sebagai alat bantu untuk mengumpulkan data-data yang dibutuhkan, yaitu:

a. Pedoman Wawancara

Pedoman wawancara yang digunakan peneliti berisi daftar pertanyaanpertanyaan yang disusun berdasarkan tujuan penelitian dan teori yang terkait. Selain itu, pedoman juga berisi data pribadi partisipan. Pedoman wawancara digunakan untuk mengingatkan peneliti mengenai faktor-faktor yang mempengaruhi stres yaitu faktor penyebab makro, faktor penyebab mikro, frustrasi, 
konfilk, tekanan, kritis, kesehatan fisik. Faktor yang mempengaruhi strategi coping yaitu keyakinan, kemampuan memecahkan masalah, kemampuan sosial, dukungan sosial, materi. Bentukbentuk stres yaitu Eustress, distress, systematis stress, psychological stress dan bentuk-bentuk coping stres yaitu problem-focused coping, emotionfocused coping sekaligus menjadi daftar untuk memeriksa apakah faktor-faktor yang mempengaruhi stres tersebut telah dibahas atau ditanyakan (Poerwandari, 2001).

b. Pedoman Observasi

Menurut Moleong (2000), pedoman observasi yang digunakan dalam bentuk catatan lapangan. Catatan ini berupa coretan seperlunya yang sangat dipersingkat, berisi kata-kata kunci, frase, pokok-pokok isi pembicaraan atau pengamatan, mungkin gambar, sketsa, sosiogram, dan lain-lain. Catatan ini berguna hanya sebagai alat perantara yaitu antara apa yang dilihat dan didengar.

Menurut Poerwandari (2001), pedoman observasi yang digunakan dalambentuk catatan lapangan. Catatan lapangan yaitu berisi deskripsi tentang hal-hal yang diamati, apapun yang dianggap oleh peneliti penting. Penulisan catatan dapat dilakukan dalam cara yang berbeda-beda, dan catatan lapangan mutlak dibuat secara lengkap dan informatif. Kemudian peneliti melakukan pencatatan secara kontinu dan menuliskan langsung saat melakukan observasi di lapangan.

3. Alat Perekam (Tape Recorder)

Alat perekam ini digunakan untuk merekam semua pembicaraan. Penggunaan Tape Recorder dalam wawancara dapat digunakan setelah peneliti mendapatkan izin dari subjek untuk mempergunakannya

4. Alat Tulis

Alat tulis digunakan untuk menulis pada lembar observasi. Penggunaan alat tulis dalam wawancara dapat digunakan pada saat wawancara berlangsung.

\section{Subjek Penelitian}

Subjek penelitian ini adalah satu pasien laki-laki penyandang amputasi transtibial yang berumur 23 tahun. Penyebab amputasi pasien yakni dikarenakan trauma kecelakaan lalu lintas ketika pasien masih duduk dibangku SMA. Pasien mulai menggunakan kaki tiruan selang 1 tahun setelah operasi amputasi. Dan sampai sekarang pasien masih menggunakan prosthesis dengan tipe eksoskeletal. Dalam kegiatan seharihari pasien merupakan mahasiswa di salah satu perguruan tinggi swasta di Surakarta. Pasien juga aktif mengikuti organisasi baik diluar kampus maupun didalam kampus. Selain berkegiatan kuliah pasien juga memliliki pekerjaan sambilan sebagai EO (Event Organizer) dan Travel Agent yang dibentuk bersama teman-teman team-nya. Pasien bertempat tinggal di daerah urban dan datar. Pasien juga nyaman menggunakan prosthesis dalam seluruh aktivitasnya dan mulai melepas prosthesis pada saat mandi, tidur dan disaat-saat tertentu saja.

\section{HASIL PENELITIAN}

\section{Keabsahan dan Keakuratan Penelitian}

Yin (1994) mengajukan empat kriteria keabsahan dan keakuratan yang diperlukan dalam suatu penelitian kualitatif, yaitu:

1. Keabsahan Konstruk (Construct
Validity)
Keabsahan konstruk berkaitan dengan
kepastian bahwa yang terukur benar-benar 
merupakan variabel yang ingin diukur. Keabsahan ini dapat dicapai dengan proses pengumpulan data yang tepat. Salah satu caranya adalah dengan proses triangulasi, yaitu teknik pemeriksaan keabsahan data yang memanfaatkan sesuatu yang lain di luar data itu untuk keperluan pengecekan atau sebagai pembanding terhadap data itu. (Patton, 2002) mengemukakan empat macam triangulasi sebagai teknik pemeriksaan untuk mencapai keabsahan, yaitu:

a. Triangulasi Data (Data Triangulation)

Menggunakan berbagai sumber data seperti dokumen, arsip, hasil wawncara, hasil observasi atau juga dengan mewawancarai lebih dari satu subjek yang dianggap mempunyai sudut pandang yang berbeda. Termasuk disini adalah wawancara dengan orang-orang terdekat subjek (significant other).

b. Triangulasi Pengamat (Investigator Triangulation)

Adanya pengamat di luar peneliti yang turut memeriksa hasil pengumpulan data. Pemanfaatan pengamatan lainnya membantu mengurangi kemelencengan dalam pengumpulan data.

c. Triangulasi Teori (Theory Triangulasi)

Yaitu penggunaan teori yang berlainan untuk memastikan bahwa data yang dikumpulkan sudah memenuhi syarat. Pada penelitian ini, berbagai teori telah dijelaskan pada bab II untuk digunakan dan menguji terkumpulnya data tersebut.

d. Triangulasi Metode (Methodological Triangulation)

Yaitu penggunaan berbagai metode untuk meneliti suatu hal, seperti metode wawancara dan observasi. Dalam penelitian ini, peneliti melakukan metode wawancara yang ditunjang dengan metode observasi pada saat wawancara dilaksanakan.

2. Keabsahan Internal (Internal Validity) Keabsahan internal merupakan konsep yang mengacu pada seberapa jauh kesimpulan hasil penelitian menggambarkan keadaan sesungguhnya. Keabsahan ini dapat dicapai melalui proses analisis dan interpretasi yang tepat. Aktivitas dalam melakukan penelitian kualitatif akan berubah dan tentunya akan mempengaruhi hasil dari penelitian tersebut. Sehingga walaupun telah dilakukan uji keabsahan internal, tetap ada kemungkinan munculnya kesimpulan yang lain yang berbeda.

3. Keabsahan Eksternal (Exsternal Validity)

Keabsahan yang mengacu pada seberapa jauh hasil penelitian dapat di generalisaikan pada kasus lain. Walaupun dalam penelitian kualitatif memiliki sifat tidak ada kesimpulan akhir yang pasti, penelitian kualitatif tetap dapat dikatakan memiliki keabsahan eksternal terhadap kasus-kasus lain selama kasus tersebut memiliki konteks yang sama.

4. Keajegan ( Reliability )

Keajegan merupakan konsep yang mengacu pada seberapa jauh penelitian berikutnya akan mencapai hasil yang sama apabila mengulang penelitian yang sama sekali lagi. Dalam penelitian kualitatif, keajegan mengacu pada kemungkinan peneliti selanjutnya memperoleh hasil yang sama apabila penelitian dilakukan sekali lagi dengan subjek yang sama. Hal ini menunjukkan bahwa konsep keajegan penelitian kualitatif selain menekankan pada desain penelitian, juga pada cara pengumpulan data dan pengolahan data.

Untuk meningkatkan keajegan diperlukan protokol penelitian yang jelas, seperti pedoman wawancara yang akan membuat pertanyaan yang diajukan akan 
lebih terarah. Hal penting lainnya adalah pertanyaan yang diajukan pada tiap subjek harus sama, dengan tujuan bila peneliti ini diulang hasil yang keluar akan sama. Walaupun dalam penelitian ini menggunakan wawancara tak terstruktur ini untuk mendapatkan gambaran yang lebih mendalam tentang subjek terlepas dari subjektivitas peneliti

\section{PEMBAHASAN}

Dalam analisa ini terdapat gambaran umum subjek, hasil observasi pemakaian knee ankle foot orthosis dan hasil wawancara dengan keluarga subjek tentang kondisi pasien sebelum dan sesudah menggunakan knee ankle foot orthosis.

\section{Gambaran Umum Subjek}

Tn.HS berumur 23 tahun, pada saat masih di bangku Sekolah Menengah Atas (SMA) mengalami trauma karena kecelakaan lintas yang mengakibatkan cedera hebat pada tungkai sebelah kanan. Kecelakaan terjadi ketika pasien sedang menikung di tanjakan dalam perjalanan saat akan pergi ke suatu tempat, tiba tiba pasien dikejutkan dengan datangnya sebuah mobil dari arah yang sama dan menyerempet pasien sehingga kecelakaan pun tidak dapat tercegah. Karena kecelakaan itu Tn.HS terjatuh dalam posisi sila dengan tungkai masuk kedalam. Dia merasakan ada tulang patah dan pendarahan karena luka namun pasien tidak pingsan atau masih keadaan sadarkan diri. Lalu pasien teringat bahwa disakunya ada ponsel dan segera memberi kabar pada ayahnya yang berada di GK disaat itu juga. Waktu itu pasien lumayan lama menunggu pertolongan dan pasien ingin menunggu polisi yang datang dikarenakan tidak ingin terjadi kesalahan nantinya.
Sesampainya pihak kepolisian dan ambulan disana pasien dilarikan ke RSUD WG. Pemeriksaan dan penanganan mulai dilakukan di unit kegawat daruratan. Waktu itu pasien masih absen dan daftar secara mandiri karena belum ada siapapun yang datang. Tidak lama kemudian pihak sekolah dan teman-temannya datang dan mewakili sebagai wali sementara agar pasien segera ditindaklanjuti untuk diberikan penanganan lagi. Peristiwa itu terjadi pada hari jumat sekitar pukul 10.00 siang. Dalam penanganan itu ditemukan adanya kerusakan tulang dan jaringan lunak. Jarak beberapa hari setelah penanganan, pagi setelah pasien baru bangun tidur ia mencium bau tidak sedap.

Dan ternyata itu berasal dari kakinya sendiri yang mulai membusuk. 4 hari setelah kejadian itu dokterpun menyerah untuk mengobati karena justru bertambah parah dan memberikan penanganan akhir yakni operasi amputasi. Saat itu pasien merasa biasa saja meskipun terkejut namun diluar ruangan banyak isak tangis keluarga dan kerabat yang mendampinginya. Seusai diamputasi pasien sadar dan berkata tidak merasakan apapun terkait perasannya. Menunggu beberapa minggu pasien baru dijadwalkan lagi untuk melakukan operasi pemasangan kulit untuk menutup luka bekas amputasi.

Barulah disaat itu pasien mulai menunjukkan emosi yang tidak terkontrol, stress dan tertekan karena sudah bosan merasakan sakit dan hospitalisasi. Pasien menolak untuk dilakukan operasi dan memberontak. Akhirnya sang ibu memberikan pasien dukungan psikologis yang membuatnya mengatakan bersedia. Selang beberapa jam setelah pemasangan kulit pasien melakukan operasi yang ketiga. Dan selang dua minggu pasien melakukan operasi yang keempat untuk 
menutup luka yang masih terbuka. Pasien menjalani rawat inap selama 41 hari terhitung dari pertama pasien masuk UGD. Kemudian pasien diperbolehkan pulang dengan waktu penyembuhan sekitar 2 bulan istirahat. Pasien mulai masuk kembali ke sekolah setelah itu karena sudah menginjak kelas XII. Waktu itu orang tua pasien sempat bingung karena sekolah pasien yang berada di WG sedangkan rumah mereka berada di GK. Hingga pada akhirnya perawat yang selama ini merawat pasien di rumah sakit menawarkan untuk tinggal di rumahnya yang di WG agar tidak terlalu jauh saat ke sekolah. Apalagi dengan kondisi pasien yang sekarang. Selama berada di sekolah dan kesehariannya pasien menggunakan bantuan kruk untuk berjalan. Pasien bersyukur sekali sejak ia masuk rumah sakit banyak teman yang memberinya dukungan moril dan materil setiap harinya hingga pasien masuk sekolah kembali. Keberadaan mereka membuat pasien tidak merasa rendah diri dan terasingkan di lingkungan sekitar maupun di sekolah. Beberapa bulan di sekolah pasien datang ke acara pameran buku di GOR WG. Waktu berkeliling mencari buku pasien tidak sengaja bertemu dengan seorang polisi. Kemudian polisi itu menanyakan tentang keadaaannya dan memberi tawaran tentang program kaki palsu dari Kick Andy. Dan akhirnya pasienpun mendaftarkan diri mengikuti program itu. Pasien masih melakukan banyak aktivitas dan kegiatan sehari-hari masih bisa dilakukan secara mandiri. Menurut pasien, dahulu ketika masih menggunakan kruk pasien masih membutuhkan orang lain untuk membantunya dalam beberapa aktivitas. Namun setelah satu tahun dan pasien membuat alat gerak ganti (transtibial prosthesis) pasien benar-benar mandiri dalam melakukan segala aktivitas baik yang ringan maupun yang berat. Salah satunya adalah berkendara sepeda motor dan saat pergi kemanapun pasien lebih merasa citra tubuhnya kembali seperti dahulu.

Sekarang pasien sudah melanjutkan pendidikan perguruan tinggi swasta di KS dan tinggal secara menyewa kost di daerah sekitar kampus. Sedangkan keluarga berdomisili di GK, Yogyakarta. Dalam kegiatannya sehari- hari pasien menggunakan prosthesis di segala aktivitas kecuali aktivitas tertentu seperti mandi dan tidur. Karena menurut pasien dia lebih mampu melakukan kegiatan fungsional lebih baik ketika memakai prosthesis. Tipe prosthesis yang digunakan yakni transtibial prosthesis eksoskeletal dengan socket stump jenis PTB-SC dan kaki jenis Sach Foot.

2. Analisis Alat Hasil Observasi Penggunaan Transtibial Prosthesis

Dari hasil observasi penggunaan transtibial prosthesis dapat dilihat bahwasannya pasien merasa mempunyai citra yang lebih baik karena memiliki kembali tungkainya yang hilang. Sebelum memakai alat, terkadang pasien menyadari hal-hal negatif tentang dirinya yang dibandingkan dengan orang lain dan juga merasa aneh saat melihat dirinya sendiri. Meskipun di keseharianya pasien tidak pernah merasa rendah diri dan mendapat dukungan dari banyak orang namun sesekali itu yang dirasakan oleh pasien. Kemudian setelah menggunakan dan belajar bagaimana pemakaian prosthesis pasien mulai menyadari dia lebih optimis ketika berada di luar ataupun saat bepergian jauh. Berdasarkan keterangan dari teman pasien yakni Nn.ID, selama ini 
Nn. ID mengenal Tn. HS adalah sosok pribadi yang ramah, enjoy dan mudah bergaul. Kondisinya yang sekarang benar-benar tidak mempengaruhinya dalam pergaulan secara umum dan menurutnya Tn. HS merasa biasa saja dan menerima citra tubuhnya dengan baik apalagi ketika melihat Tn. HS yang memakai kaki tiruan (prosthesis) dia merasa bahwa Tn. HS semakin optimis saat melakukan aktivitasnya yang kebanyakan berada diluar ruangan. Dan yang lebih membuat Nn.ID terkesan bahwasannya Tn. HS termasuk orang yang pandai bersyukur dan taat beribadah meskipun dalam kondisinya yang sekarang.

Ketika pasien melakukan proses latihan menggunakan prosthesis yang kedua tidak banyak penyimpangan pola jalan yang diperoleh pasien. Pola jalannya cukup baik dan yang terpenting pasien merasa nyaman saat melangkahkan kakinya walaupun itu baru kali pertama bagi pasien dengan kondisi teramputasi. Waktu yang dibutuhkan pasien untuk melakukan pelatihan pemakaian prosthesis juga relatif singkat yakni sekitar beberapa minggu. Disamping melakukan pelatihan pasien juga memperbaiki pola jalannya agar terlihat seperti orang normal yang ketika berjalan seperti tidak menggunakan prosthesis. Sampai sekarang pasien sudah mengganti prosthesisnya sebanyak 2 kali tanpa memakai kruk. Selain itu pasien juga rutin merawat stumpnya apabila tejadi lecet akibat pemakaian prosthesis yang terus menerus dan untuk menjaga kebersihan stumpnya.

\section{KESIMPULAN DAN SARAN}

Berdasarkan hasil observasi, wawancara dan analisa yang dilakukan terhadap penggunaan Transtibial Prosthesis, kini pasien merasakan kemajuan dalam beraktivitas berkat menggunakan prosthesis terlebih saat aktivitas itu harus berada di muka umum. Dalam proses pembuatan alatnya dan pelatihan berjalan, pada pasien tidak ditemui pola jalan yang terlalu bermasalah, demikian menurut pasien berdasarkan yang disampaikan oleh ortotis prostetisnya. Maka dapat disimpulkan, bahwa penggunaan Transtibial Prosthesis dapat membantu menambah citra tubuh dengan cara menggantikan tungkai pasien yang hilang akibat amputasi.

Adapun saran yang dapat diberikan oleh peneliti yakni sebaiknya pasien yang mengalami operasi amputasi membuatkan alat gerak ganti untuk mengembalikan bagian yang telah hilang. Karena selain untuk menambah citra tubuh menjadi lebih baik, pembuatan prosthesis juga membantu secara anatomis dan dalam aktivitas fungsional.

\section{DAFTAR RUJUKAN}

Cartwright, C.A, \& Cartwright, P,G, "Developing Observation Skills" ${ }^{2 n d}$ ed, USA: Mc Graw- Hill, 1984

Cash, T. F. (1994). Body Image Attitudes : Evaluation, Investment, \& Affect Perceptual and Motor Skills. Journal of Psychology, 78, 1168-1170.

Handicap International. (2006). Guideline for Prosthesis Management. Handicap International, Paris.

Honigman, David j. Castle. (2007). Living With Your Looks. Victoria: University Of Western Australia Press

Moleong, J.L. (1998) Metodologi penelitian kualitatif. Bandung: PT. Remaja Rosdakarya. 
Moleong, J.L. (2000) Metodologi penelitian kualitatif (Edisi Revisi). Bandung: PT. Remaja Rosdakarya.

Naimah, T. (2008). Pengaruh Komparasi Sosial pada Public Figure di Media Massa terhadap Body Image Remaja Di Kecamatan Patikraja, Kabupaten Banyumas. Jurnal Psikologi Penelitian Humaniora, 9, (2).

Patton, Q.M. (2002) Qualitative research and evaluation metode. $3^{\text {nd }}$ ed. California: Sage Publication, Inc.

Permenkes RI. (2013). Pengertian Ortotik Prostetik : 22.

Poerwandari, K. (2001) Pendekatan Kualitatif Untuk Penelitian Perilaku Manusia .Jakarta: Lembaga PengembanganSarana Pengukuran \& Pendidikan Psikologi (LPSP 3) Universitas Indonesia.

Qkey. (2007). Free Medical Amputasi. Diakses tanggal 16/10/2017, dari http/www.freemedical.blogspot.co $\mathrm{m}$

Tika Larasati. (2012). Jurnal Kualitas Hidup Pada Wanita Yang Sudah Memasuki Masa Menopause. Fakultas Psikologi Universitas Gunadarma, Depok.

Vitriana. (2002). Rehabilitasi Pasien Amputasi Bawah Lutut Dengan

Menggunakan Immediate Post Operative Prosthetic. Penelitian Bagian Ilmu Kedokteran Fisik dan Rehabilitasi. FK-UNPAD, Bandung, hal 1-3.

Yin, R. (1994) Case study research design \& method. London: Sage Publication 